\title{
Access to Debt Finance: Which Policies Work? Empirical Evidence from Sub-Saharan Africa
}

\author{
Prosper Senyo Koto
}

\author{
Department of Economics, Dalhousie University, 6214 University Avenue, PO Box 15000, Halifax, NS B3H \\ 4R2, Canada
}

\begin{abstract}
Are the structural policy reforms effective in reducing debt financing constraints on formal sector enterprises in sub-Saharan Africa? We do not know. And the reason is the relatively limited research on the effectiveness of policies in the credit market. Using policy variables from the World Bank and the Enterprise Surveys data, the analysis involves three-way error component models. The results are indicative that taken together; structural policy reforms reduce debt financing constraints, at least, as it pertains to working capital needs. There is heterogeneity in the results. Changes in the business regulatory environment benefit large firms more than small ones. Financial sector reforms affect enterprises of all sizes relatively equally. For all the twelve countries, together, trade sector reforms initially increase the likelihood of access to debt finance by 20 percent until a policy threshold, beyond which progressive reforms in the trade sector reduce the probability by as much as 13 percent. Also, not all countries experience the same effects from trade sector reforms. The result is robust to different indicators of credit constraint and measures of structural reforms. The results have implications on the World Bank's push towards reforms on trade policy across countries.
\end{abstract}

Keywords: Debt-financing, trade reforms, structural reforms.

\section{INTRODUCTION}

Are the structural policy reforms effective in reducing debt financing constraints on formal sector enterprises in sub-Saharan Africa? One would think that the answer to the question above is an obvious yes. But, in fact, the answer remains unknown. And the reason is the relatively limited research on the effectiveness of policies in the credit market, especially in sub-Saharan Africa. The theoretical literature on dual and common agency problems in the credit market suggest a role for policy in easing financing constraints on enterprises. However, the effectiveness of specific policies remains unknown. This paper examines the issue of whether or not structural reforms, as defined by the World Bank within the context of the Country Policy and Institutional Assessment reports, can influence the credit climate for particular firms in subSahara Africa.

The World Bank (2013), observes that the perceptions of the regulatory environment in various economies affect start-up rates of enterprises, thereby affecting job creation. Consequently, in recent years, the World Bank has highlighted the importance of creating an enabling environment for businesses to thrive. Earlier research on enterprise financing constraints, including Kuntchev et al. (2014), Ayyagari, Demirgüç-Kunt, \& Maksimovic (2008), Beck and Demirguc-Kunt (2006) and Kaplan and Zingales

*Address of correspondence to this author at the Department of Economics, Dalhousie University, 6214 University Avenue, PO Box 15000, Halifax, NS B3H 4R2, Canada; Tel: +1 204881 1780; E-mail: Prosper.Koto@Dal.ca
(1997), have tended to focus on the effects of financing constraints on enterprise growth, with limited research on the effectiveness of policies in the credit market.

Small and Medium Scale Enterprises, (SMEs) which constitute over $95 \%$ of the enterprises in the sample, contribute to job creation and economic growth. Ayyagari, Demirguc-Kunt, \& Maksimovic (2011) write that $95 \%$ of enterprises in the world are SMEs and account for about $60 \%$ of jobs created in the private sector. In South Africa, Abor \& Quartey (2010), reports that $91 \%$ of the formal sector enterprises are SMEs and account for $61 \%$ of total employment. In the case of Ghana, Abor and Quartey (2010) report that SMEs contribute $92 \%$ of local businesses and $70 \%$ on average, to Ghana's GDP, while accounting for $80 \%$ of total jobs in the Ghanaian economy. Therefore, addressing financing constraints facing enterprises is of the first order.

The data is from three sources, namely, the Country Policy and Institutional Assessment (CPIA) reports, Economic Freedom Index from the Fraser Institute, as reported by Gwartney, Lawson, \& Hall (2013), and the World Bank Enterprise Surveys (WBES). The CPIA attempts to measure the conduciveness of a country's institutional and policy environment for economic growth. There are twelve (12) countries from subSaharan Africa in the sample. The sample size is up to 9,366 enterprises with 8,002 longitudinally observed enterprises. For each enterprise in each country, there are two non-consecutive data points. The analyses involve three-way error component random effects 
panel data models. The choice of the model driven by nature of the left-hand side variables.

There are two left-hand side variables (indicators of the credit status of an enterprise). The indicators of the financial situation of the enterprise are status, a derived ordered outcome variable following Kuntchev et al. (2014), and credit; a binary outcome variable based on whether or not enterprises had access to a line of credit or loan or not. Credit comes from responses to the question "at this time, does this establishment have a line of credit or a loan from a financial institution?" Facilities with loans or lines of credit get a value of one and zero otherwise. Status would be measuring the effect of access to finance on investment, while credit would be measuring the effects of access to finance on working capital. Structural policy index (reform) constitute the primary explanatory variable. The structural policy variable is an index consisting of trade, financial sector reforms, and the business regulatory environment.

After controlling for enterprise, country, and time effects, the results are indicative that taken together; structural policy reforms reduce debt financing constraints facing enterprises, at least, as it pertains to their working capital needs. There is heterogeneity in the results. Changes in the business regulatory environment benefit large firms more than small ones. Financial sector reforms affect enterprises of all sizes relatively equally. There is additional heterogeneity in the consequences of trade sector reforms. For all the twelve countries, together, trade sector reforms initially increase the likelihood of access to debt financing by 20 percent until a policy score of 3.5. Beyond a score of 3.5 , progressive reforms in the trade sector reduce the probability by as much as 13 percent. Also, not all countries experience the same effects from trade sector reforms. Improvements in the score on trade sector reforms have adverse effects on the probability of access to debt finance by enterprises in Angola and Democratic Republic of Congo, for instance. However, the effect is positive for Rwanda. These results present a challenge to the uniform reforms promoted by the World Bank. The results are robust to different specifications and policy variables.

The present study contributes to various strands of the literature. It relates to the research on financing entrepreneurship and SMEs. It represents an empirical adaptation of the theoretical model on the dual and common agency problems in the credit market by Tirole (2006). The present study is one of the few studies to examine empirically, the impact of financial sector reforms in the credit market. It also builds on and extends an earlier study by Kuntchev et al. (2014). It builds on that study in the sense that it uses their approach in identifying credit-constrained enterprises but differs in method and policy variables analyzed. Kuntchev et al. (2014) use cross-sectional data while the current study uses panel data.

\section{LITERATURE REVIEW}

Before the seminal work by Schumpeter (1934), economic theory treated the financial sector as playing a minor role in the process of economic growth. The insight of Schumpeter led to changes. In their seminal paper, Gurley \& Shaw (1955) argue that at low levels of economic growth, firms self-finance their investments and switch to debt finance as the economy grows. Financial markets and institutions, acting as intermediaries, become principal actors in investment financing, which in turn, influences long-term economic growth. Goldsmith (1969) also find that as economies grow, banks and nonbank financial institutions grow in importance in the economy, highlighting the role of financial markets and institutions for economic growth. How do SMEs finance their investments? Beck et al. (2009), in a literature review, observe that enterprises in developing countries have difficulty accessing resources for investment. They note that the inability of enterprises to access external finance for investment is a binding constraint on economic growth in developing countries. Beck et al. (2009), argue for government policies that provide greater access to finance. Fazzari, Hubbard, Petersen, Blinder, \& James (1988) observe that due to asymmetric information, internal and external sources of financing are not perfect substitutes; external finance is more costly than internal finance. Du \& Girma (2012) support this view, arguing that because the fixed cost of raising external funds is non-trivial for small enterprises, size is important in determining access to finance.

Beck \& Demirguc-Kunt (2006) also find that size, age, and ownership structure of an enterprise are determinants of access to finance-older, larger, and foreign-owned enterprises are less likely to be credit constrained. Cassar (2004) on the other hand, observe that creditors might perceive incorporation as a sign of credibility and formality of operations, as such; incorporated enterprises are likely to have more access to debt finance. On the role of policy in easing credit constraints, Ayyagari, Demirgüç-Kunt, \& Maksimovic (2008) find that instability in the policy environment 
negatively affects enterprise growth. However, the effectiveness of specific policies in the credit market remains inconclusive.

Another issue relevant to the financing constraint literature is the use of trade credit by enterprises. On the supply of trade credit, Burkart \& Ellingsen (2004) explain that the relative illiquidity of inputs makes it difficult for firms to divert for personal gain, unlike loans, providing an opportunity for suppliers of trade credit to reduce the moral hazard and adverse selection problems associated with loans. On the demand side, it is not too obvious why enterprises require or use trade credit, despite it being a very expensive source of credit. Tirole (2006) reports that the terms of a trade credit contract are typically not favorable to enterprises. In the U.S., Tirole states that in some cases, the overall cost of the trade credit is as much as $37.24 \%$ per annum. According to Smith (1987), to creditors in the capital market, possession of a trade credit contract is a signal of borrower type. The implication is that in certain situations, trade credit functions as a screening device.

Tirole (2006, p. 546-549) provides a framework for thinking about how policy can influence credit contracts, and hence, credit constraints in the credit market. Tirole observes that for a private financing agreement between a lender and a borrower, lender returns depends on the behavior of the borrower, and the policy choices of the borrower's government. Financial arrangements between creditors and borrowers influence each other through their impact on the incentives of the government of the borrower. The government is the common agent of all participants in the financing contract. A profit-enhancing policy action by the government that signals the protection for the rights of lenders and borrowers alike induces more financing deals and reduces the likelihood that an enterprise is a credit-constrained one. The empirical analysis in this paper proceeds with the assumption that the government chooses and commits to its policy actions, placing equal weights on the borrowers and creditors. Enterprises that can raise funds can finance their investments, hence are not financially constrained. Those unable to sign financing contracts will not be able to fund their investments, hence, will be credit constrained.

Any empirical study on 'credit constrained enterprises' has to contend with the characterisation of a credit-constrained enterprise-how does one objectively identify one, and from whose perspective?
There are two approaches in the literature. The first method involves analyzing the financial reports of firms, if available. The second method includes the use of responses to survey questions. Kaplan \& Zingales (2000) classified enterprises based on qualitative and quantitative information contained in their annual financial reports. They identify enterprises without access to more resources than needed to fund their investment as credit constrained, and those with access as unconstrained. However, Fazzari, Hubbard, \& Petersen, (2000) observe that the data used by Kaplan \& Zingales (2000) coincided with years in which the enterprises were financially distressed and, therefore, presents a distorted view of their financial positions.

Bigsten, Collier, \& Dercon (2003) provide another classification scheme using survey data. Based on why enterprises did not apply for loans, they grouped them into three. The first group consists of "financially unconstrained enterprises without credit demand"; this group consists of enterprises that did not apply for loans because they did not need one. The second group consists of "financially constrained enterprises;" this group consists of those that applied for loans, but the application rejected, enterprises that did not have enough collateral, enterprises that considered the application process too complicated, and enterprises who anticipated rejection even if they were willing to pay the current interest rates. The third group consists of "financially unconstrained enterprises with credit demand"; this group consists of those that obtained loans.

Kuntchev et al. (2014) present a variant of the scheme by Bigsten, Collier, \& Dercon (2003) using enterprise level data from the World Bank Enterprise Surveys (WBES). They classify enterprises into "not credit constrained," "may be credit constrained," "partially credit constrained," and "fully credit constrained." Figure 1 presents a schematic representation of their classification scheme. This study adopts the classification system by Kuntchev et al. (2014) in measuring one of the three indicators of the credit constraint status of enterprises.

Thus, far, the previous studies focused on the enterprise specific characteristics without much attention to whether or not; structural policy reforms can be effective in reducing debt-financing constraints on enterprises. This gap in the literature is a significant omission since businesses, and financial institutions do 
not exist and operate in isolation; they function in a particular institutional and regulatory framework.

\section{IDENTIFICATION STRATEGY AND DATA}

\subsection{Identification Strategy}

The analyses involve a three-way error component model of the form

$y_{i c t}=\ln \left(\right.$ reform $\left._{c t}\right) \beta_{1}+x_{i c t}^{\prime} \beta_{2}+z_{i c}^{\prime} \beta_{3}+$

credit to private sec tor $/ G D P_{c t} \beta_{4}+u_{i c t}$

Where $u_{i c t}=\mu_{i}+\eta_{c}+\lambda_{t}+v_{i c t}$

$(i=1, \ldots, N, t=1, \ldots, T ; c, \ldots, M)$

Where $y_{\text {ict }}$ is one of the two indicators of access to debt financing: credit-whether an enterprise $i$ in country $c$ at time $t$ has a line of credit or loan or not, and the derived ordinal outcome variable, status, following Kuntchev et al. (2014).

Kuntchev et al. (2014) classify enterprises into "not credit constrained (NCC)," "may be credit constrained (MCC)," "partially credit constrained (PCC)" and "fully credit constrained (FCC)" using data from the World
Bank Enterprise Surveys (WBES). Figure 1 shows a schematic representation of the classification scheme. According to Kuntchev et al. (2014), a fully credit constrained enterprise must have applied for credit in the past fiscal year, and the application rejected. Also, the enterprise should not have outstanding loans from the formal credit market at the time of data collection. A fully credit constrained enterprise also includes enterprises that did not apply for credit in the past fiscal year, because of reasons other than having enough capital. A partially credit constrained is one that applied for loans or lines of credit but does not have bank financing. Those in this category may have informal financing. A business may be constrained if it applied for loans and has bank financing. Those that do not have debt finance and did not request a loan in the earlier fiscal year and the reason they did not apply is that they had enough capital are not credit constrained. The ordinal variable Status comes from the four categories, where NCC takes a value of one, MCC as two, PCC as three, and FCC as four. Credit is a binary variable based on whether enterprises had access to a line of credit or loan or not. This variable comes from responses to the question "at this time, does this establishment have a line of credit or a loan from a

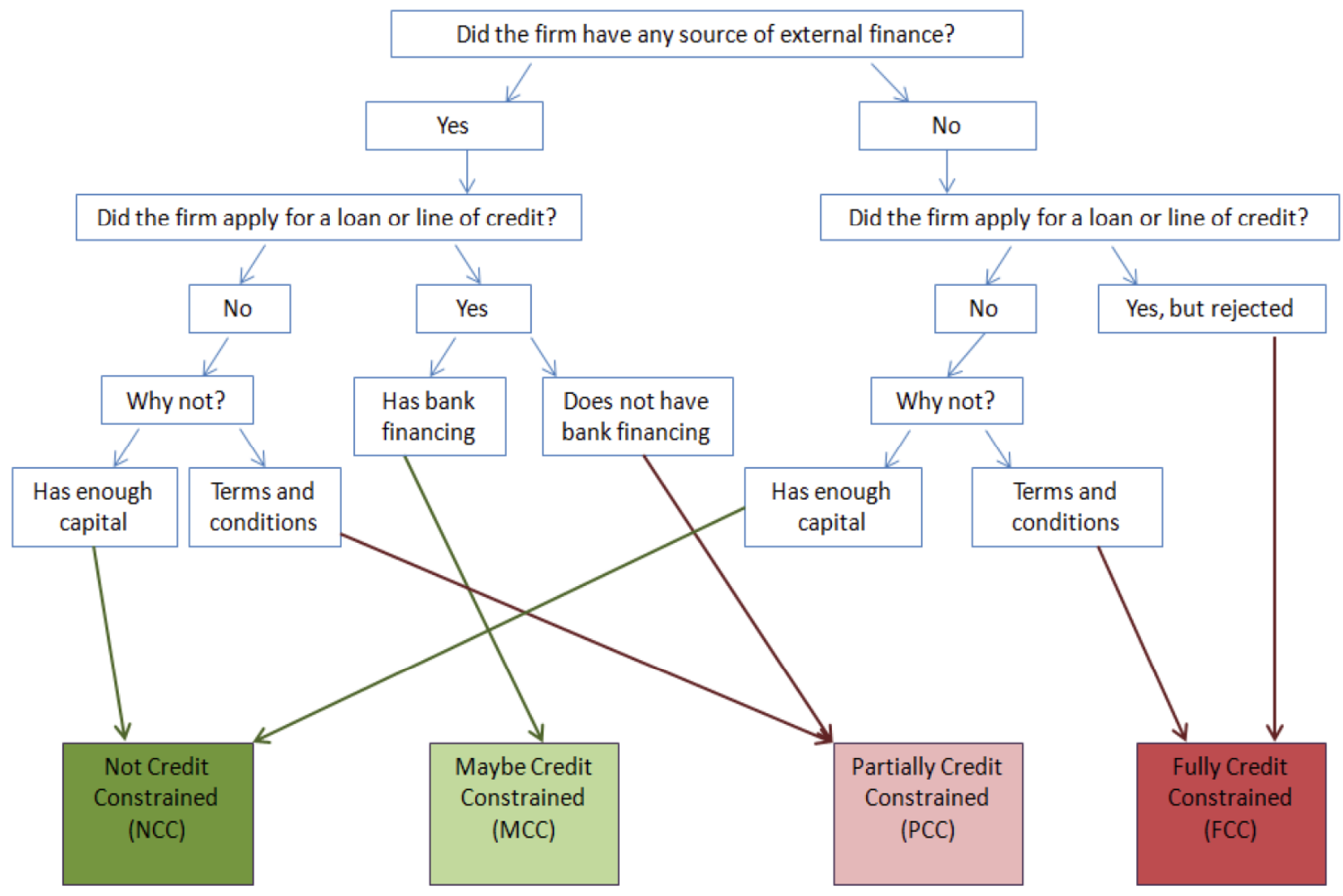

Figure 1: Categories in the outcome variable status.

Source: Kuntchev et al. (2014). 
financial institution?" Facilities with loans or lines of credit get a value of one and zero otherwise.

The primary explanatory variable is reform ct which captures time varying structural policy reforms in the various countries. It represents the World Bank's Country Policy and Institutional Assessment (CPIA, 2013) index on structural policy reforms. The structural policy reforms cover trade, financial sector reforms, and the business regulatory environment. The trade component attempts to assess how the policy framework fosters regional and global integration in goods and services, focusing on the trade policy regime and trade facilitation. Assessment of the trade regime covers tariffs, non-tariff barriers, and obstacles to trade in services. On the financial sector, the CPIA measures policies and regulations that affect financial stability, efficiency, and access. The business regulatory environment component attempts to assess the degree to which the quality of the policy, legal, and regulatory framework for enterprises is profit-friendly to attract private investment. The regulatory framework includes enforcement of contracts, collateral registry, regulations on entry, exit, and competition, regulations on businesses in operations and regulations concerning land and labour. The index on structural reforms is on a six-point scale-with a 1-point rating corresponding to the lowest recorded performance while a 6-point rating corresponds to highest recorded performance.

The control variables include $x_{i c t}$ which is a vector of time varying enterprise characteristics comprising age, and size of the entreprise, following Beck \& Demirguc-Kunt (2006). Concerning size, enterprises with at least five but less than twenty full-time workers are small; those with a full-time staff of between twenty and ninety-nine are medium; and those with more than hundred employees, large. $z_{i c}$ a vector of time independent variables, include registration status at start up following Cassar (2004), gender of the manager following Kuntchev et al. (2014), the ownership structure of the enterprise - foreign-owned, sole proprietorship, product market, the legal status of the enterprise, use of trade credit, following Petersen \& Rajan (1997) and Tirole (2006), and type of industry (manufacturing or services). Credit to private sector/GDP $P_{c t}$ denote the share of credit to the private sector as a percentage of GDP, following Kuntchev et al. (2014). There is control for year of sampling. $\mu_{i}$ denotes the unobserved enterprise specific heterogeneity; $\eta_{c}$ denotes country specific effect. $\lambda_{t}$ denotes time specific effect and $v_{i c t}$ denotes the remainder disturbance, assumed independently and identically distributed.

Greene (2012, p. 717) reports that in the case of binary choice models with panel data, in estimating a fixed effects model of equation (1), one has to contend with incidental parameters problem. This issue, Greene argues, makes the maximum likelihood estimator inconsistent. The random effects model too, Greene (2012) argues, requires the assumption that $\mu_{i}$ and $x_{i t}$ are uncorrelated, but offers consistent estimates, hence it is the approach adopted in the estimation of equation (1). Concerning the outcome variable status, Pfarr (2011) observes that the random effects generalised ordered probit specification preserve the unobserved enterprise heterogeneity. The estimation proceeds in two stages. First, in the basic model, there is an estimation of each model using the composite form of the primary explanatory variable, reform (for structural policy reforms index) and the control variables. If the primary explanatory variable is statistically significant, the second stage involves reestimating the model, but this time, using the disaggregated policy variables.

\subsection{Data}

The analysis uses three data sources. The primary explanatory variables come from the Country Policy and Institutional Assessment (CPIA, 2013) reports, and the Economic Freedom Index (EFI) from the Fraser Institute, as reported by Gwartney, Lawson, \& Hall (2013) (for robustness checks), and the World Bank Enterprise Survey (WBES). The left-hand side variables and the enterprise level variables come from the WBES. Data on the share of credit to the private sector comes from the World Development Indicators Database. There are twelve (12) countries from subSaharan Africa in the sample. The sample size is up to 9,366 enterprises with 8,002 longitudinally observed enterprises. Table 1 presents a breakdown of the enterprises across countries in the sample. Table 2 show the outcome variables in the sample. Table 3 present summary statistics of the variables. Figure 2 shows what enterprises in sub-Saharan Africa consider constraints on their operations, constructed from data from the WBES over the period 2009 to 2013. From the Figure, over $22 \%$ of the enterprises interviewed selected access to finance as a constraint. The average for all countries is $16 \%$. When the survey question asks whether access to finance is a major obstacle, twenty-eight percent $(28 \%)$ of all enterprises in the sample responded yes. Across the countries in 
Table 1: Distribution of Enterprises Across Countries in the Sample

\begin{tabular}{|c|c|c|c|c|}
\hline Country & Sample Size & Number of Panels & \multicolumn{2}{|c|}{ Sample Period } \\
\hline Angola & 449 & 363 & 2006 & 2010 \\
\hline Burkina Faso & 533 & 445 & 2005 & 2009 \\
\hline Cameroon & 535 & 460 & 2005 & 2009 \\
\hline Cape Verde & 254 & 201 & 2005 & 2009 \\
\hline Ghana & 1214 & 751 & 2007 & 2013 \\
\hline Kenya & 1370 & 1287 & 2007 & 2013 \\
\hline Malawi & 310 & 233 & 2005 & 2009 \\
\hline Rwanda & 453 & 383 & 2006 & 2010 \\
\hline Total & 9,366 & 8,002 & & \\
\hline
\end{tabular}

Source: The author's compilation based on data from the WBES database.

Table 2: Distribution of Credit and Status in the Sample

\begin{tabular}{|c|c|c|c|c|c|c|}
\hline Country & Variable & Credit & NCC & MCC & PCC & FCC \\
\hline \multirow[t]{2}{*}{ Angola } & Total & 449 & 449 & 449 & 449 & 449 \\
\hline & Percentage & $9.13 \%$ & $36.75 \%$ & $5.35 \%$ & $12.69 \%$ & $31.85 \%$ \\
\hline \multirow[t]{2}{*}{ Burkina Faso } & Total & 533 & 533 & 533 & 533 & 533 \\
\hline & Percentage & $28.71 \%$ & $14.26 \%$ & $21.58 \%$ & $20.26 \%$ & $27.20 \%$ \\
\hline \multirow[t]{2}{*}{ Cameroon } & Total & 535 & 535 & 535 & 535 & 535 \\
\hline & Percentage & $36.82 \%$ & $18.13 \%$ & $33.83 \%$ & $27.29 \%$ & $16.07 \%$ \\
\hline \multirow[t]{2}{*}{ Cape Verde } & Total & 254 & 254 & 254 & 254 & 254 \\
\hline & Percentage & $41.73 \%$ & $33.86 \%$ & $19.29 \%$ & $17.32 \%$ & $23.23 \%$ \\
\hline \multirow[t]{2}{*}{ Congo, D. R. } & Total & 699 & 699 & 699 & 699 & 699 \\
\hline & Percentage & $9.59 \%$ & $14.02 \%$ & $7.01 \%$ & $24.18 \%$ & $38.63 \%$ \\
\hline \multirow[t]{2}{*}{ Kenya } & Total & 1370 & 1370 & 1370 & 1370 & 1370 \\
\hline & Percentage & $39.12 \%$ & $23.36 \%$ & $11.39 \%$ & $8.76 \%$ & $5.18 \%$ \\
\hline \multirow[t]{2}{*}{ Malawi } & Total & 310 & 310 & 310 & 310 & 310 \\
\hline & Percentage & $34.52 \%$ & $17.10 \%$ & $17.74 \%$ & $14.84 \%$ & $30.00 \%$ \\
\hline \multirow[t]{2}{*}{ Rwanda } & Total & 453 & 453 & 453 & 453 & 453 \\
\hline & Percentage & $41.28 \%$ & $0.00 \%$ & $28.26 \%$ & $12.58 \%$ & $5.74 \%$ \\
\hline \multirow[t]{2}{*}{ Tanzania } & Total & 1142 & 1142 & 1142 & 1142 & 1142 \\
\hline & Percentage & $15.76 \%$ & $24.08 \%$ & $9.02 \%$ & $36.43 \%$ & $22.15 \%$ \\
\hline \multirow[t]{2}{*}{ Uganda } & Total & 1203 & 1203 & 1203 & 1203 & 1203 \\
\hline & Percentage & $18.12 \%$ & $31.26 \%$ & $8.81 \%$ & $32.34 \%$ & $20.45 \%$ \\
\hline \multirow[t]{2}{*}{ Zambia } & Total & 1204 & 1204 & 1204 & 1204 & 1204 \\
\hline & Percentage & $8.47 \%$ & $41.03 \%$ & $7.81 \%$ & $24.75 \%$ & $22.84 \%$ \\
\hline \multirow{3}{*}{$\begin{array}{c}\text { Ghana } \\
\text { Total }\end{array}$} & Total & 1214 & 1214 & 1214 & 1214 & 1214 \\
\hline & Percentage & $20.18 \%$ & $20.26 \%$ & $15.40 \%$ & $34.68 \%$ & $23.48 \%$ \\
\hline & Percentage & $22.84 \%$ & $24.41 \%$ & $13.31 \%$ & $24.25 \%$ & $20.84 \%$ \\
\hline
\end{tabular}

Source: The author's computation based on data from the WBES database. 
Table 3: Summary Statistics

\begin{tabular}{|c|c|c|c|c|c|}
\hline Variable & Observations & Mean & Std. Dev. & Min & Max \\
\hline Status & 9,366 & 2.071 & 1.415 & 1.000 & 4.000 \\
\hline Reforms & 9,366 & 3.599 & 0.430 & 2.333 & 4.000 \\
\hline Business regulations & 9,366 & 3.513 & 0.618 & 2.000 & 4.500 \\
\hline Trade Sector reforms & 9,366 & 3.904 & 0.317 & 3.000 & 4.500 \\
\hline Financial Sector Reforms & 9,366 & 3.323 & 0.540 & 2.000 & 4.000 \\
\hline Share of credit to private sector & 9,366 & 0.160 & 0.092 & 0.021 & 0.646 \\
\hline Size & 7,909 & 1.512 & 0.701 & 0.000 & 3.000 \\
\hline Age & 9,202 & 7.704 & 8.959 & 0.000 & 58.474 \\
\hline Foreign Ownership & 9,366 & 0.165 & 0.372 & 0.000 & 1.000 \\
\hline Trade credit & 9,366 & 0.440 & 0.496 & 0.000 & 1.000 \\
\hline Share traded & 9,366 & 0.217 & 0.412 & 0.000 & 1.000 \\
\hline Female Managed & 9,366 & 0.120 & 0.325 & 0.000 & 1.000 \\
\hline Retail & 9,366 & 0.186 & 0.389 & 0.000 & 1.000 \\
\hline Services & 9,366 & 0.282 & 0.450 & 0.000 & 1.000 \\
\hline Manufacturing & 9,366 & 0.507 & 0.500 & 0.000 & 1.000 \\
\hline Sole Proprietorship & 9,366 & 0.469 & 0.499 & 0.000 & 1.000 \\
\hline
\end{tabular}

Source: The author's compilation based on data from the WBES database.

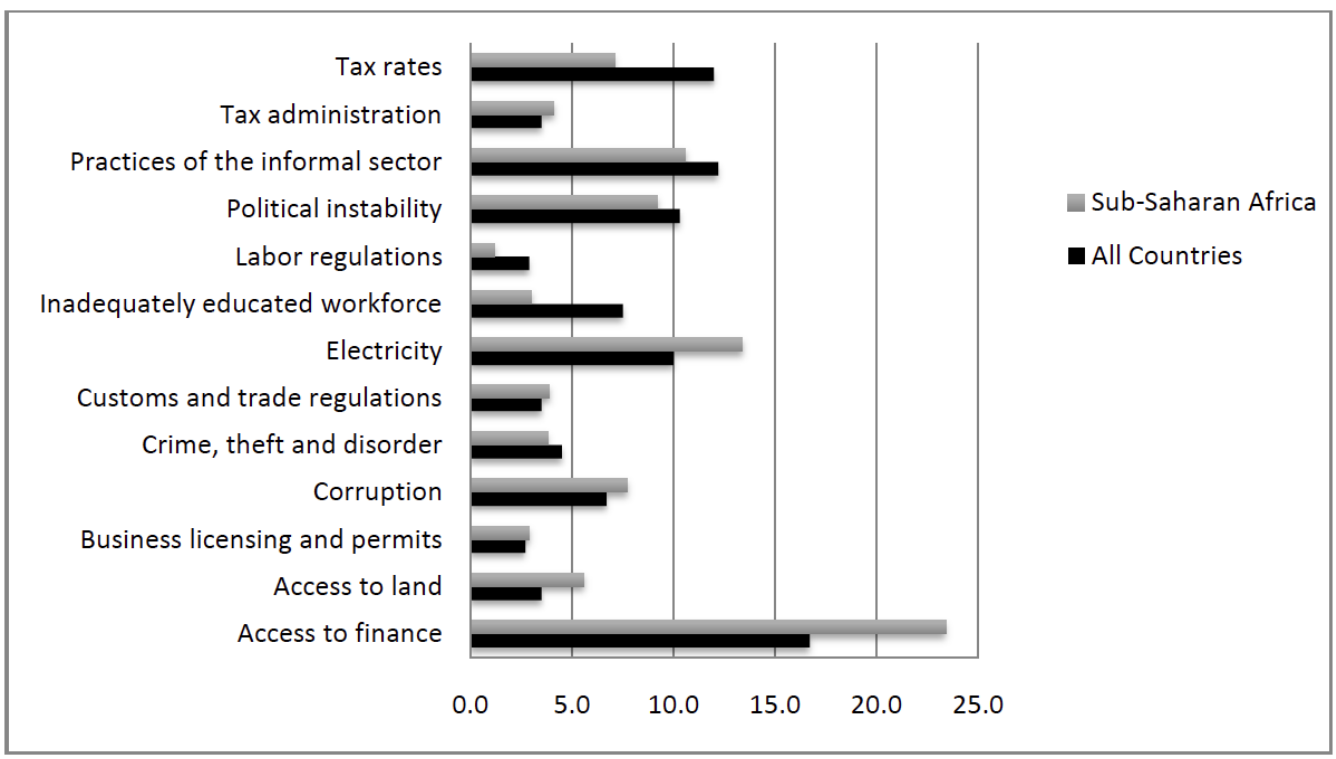

Figure 2: Business Environment Constraints.

Source: Author's calculation based on data from the WBES.

sub-Saharan Africa, the average is $42 \%$, ranging from a low of $15 \%$ in Kenya to a high of $75 \%$ in Burkina Faso.

\section{RESULTS}

Table 4 presents the marginal effects of the threeway error component model for the binary outcome variable, credit with the composite form of the primary explanatory variable, reform. The discussion of the results proceeds with the simplifying assumption that the control variables in the model do not have causal effects. From Table 4, the coefficient on reform is statistically significant at 1 percent. A 10 percent increase in the score on the structural policy index in a 
Table 4: Random Effects Probit Estimates for Credit Model

\begin{tabular}{|c|c|c|c|c|c|}
\hline \multicolumn{6}{|c|}{ Dependent variable: credit } \\
\hline & (1) & (2) & (3) & (4) & (5) \\
\hline \multirow[t]{2}{*}{$\ln ($ reform $)$} & $1.268^{* * *}$ & $0.479^{* *}$ & $0.499^{*}$ & $1.521^{* * *}$ & $1.453^{* * *}$ \\
\hline & $(0.172)$ & $(0.168)$ & $(0.199)$ & $(0.329)$ & $(0.328)$ \\
\hline \multirow[t]{2}{*}{ Private sector $\mathrm{Cr} / \mathrm{GDP}$} & & $3.076^{* * * *}$ & $2.019^{* * * *}$ & $1.303^{\text {*t*t }}$ & $1.134^{* * * *}$ \\
\hline & & $(0.265)$ & $(0.287)$ & $(0.305)$ & $(0.313)$ \\
\hline $\ln ($ size $)$ & & & $(0.0679)$ & $(0.0668)$ & $(0.0669)$ \\
\hline \multirow[t]{2}{*}{$\ln ($ age $)$} & & & $0.158^{* * *}$ & $0.162^{* * *}$ & $0.169^{* * *}$ \\
\hline & & & $(0.0201)$ & $(0.0201)$ & $(0.0207)$ \\
\hline Foreign-owned & & & $-0.195^{* *}$ & $-0.182^{* *}$ & $-0.188^{* *}$ \\
\hline Trade credit & & & $(0.0596)$ & $(0.0596)$ & $(0.0598)$ \\
\hline \multirow[t]{2}{*}{ Share traded } & & & 0.0516 & 0.0997 & $0.149^{*}$ \\
\hline & & & $(0.0632)$ & $(0.0637)$ & $(0.0678)$ \\
\hline \multirow[t]{2}{*}{ Female Manager } & & & 0.0881 & 0.112 & 0.103 \\
\hline & & & $(0.0684)$ & $(0.0680)$ & $(0.0681)$ \\
\hline \multirow[t]{2}{*}{ Retail } & & & $-0.513^{* *}$ & $-0.424^{\star *}$ & $-0.445^{* *}$ \\
\hline & & & $(0.159)$ & $(0.157)$ & $(0.159)$ \\
\hline \multirow[t]{2}{*}{ Services } & & & $-0.421^{\star *}$ & $-0.303^{*}$ & $-0.319^{*}$ \\
\hline & & & $(0.154)$ & $(0.152)$ & $(0.154)$ \\
\hline Year controls & & & No & No & Yes \\
\hline \multicolumn{6}{|l|}{$R^{2}$} \\
\hline$A / C$ & 9920.9 & 9726.3 & 7142.6 & 7117.5 & 7114.4 \\
\hline$B I C$ & 9942.3 & 9754.9 & 7240.0 & 7221.8 & 7225.7 \\
\hline \multicolumn{6}{|l|}{$\mathrm{F}$} \\
\hline Observations & 9366 & 9366 & 7754 & 7754 & 7754 \\
\hline
\end{tabular}

Marginal effects; Standard errors in parentheses (d) for discrete change of dummy variable from 0 to $1 ;{ }^{* *} p<0.05,{ }^{* *} p<0.01,{ }^{* * *} p<0.001$.

country, increases the probability that enterprises in the country have access to loans or lines of credit by 0.15 . By implication, as the policy environment improves, there is a higher chance of an enterprise having access to debt financing to finance working capital needs. Figure 3 is an illustration of the effects of progressive increases in reform on the probability of having debt finance. From Figure 4, incremental improvements in the policy environment make it easier for enterprises to access debt finance.
The next step is the augmenting the model with the disaggregated policy variables. Again, reform is an index consisting of three (3) components: business regulatory environment, financial sector reforms, and trade policy. Which of these three policymakers ought to prioritize? For policy relevance, there is a repeat of the analysis, but this time, using the disaggregated policy variables. Table 5 reports the marginal effects, again from the three-way error component model with statistically significant policy variables. From Table $\mathbf{5}$, a 


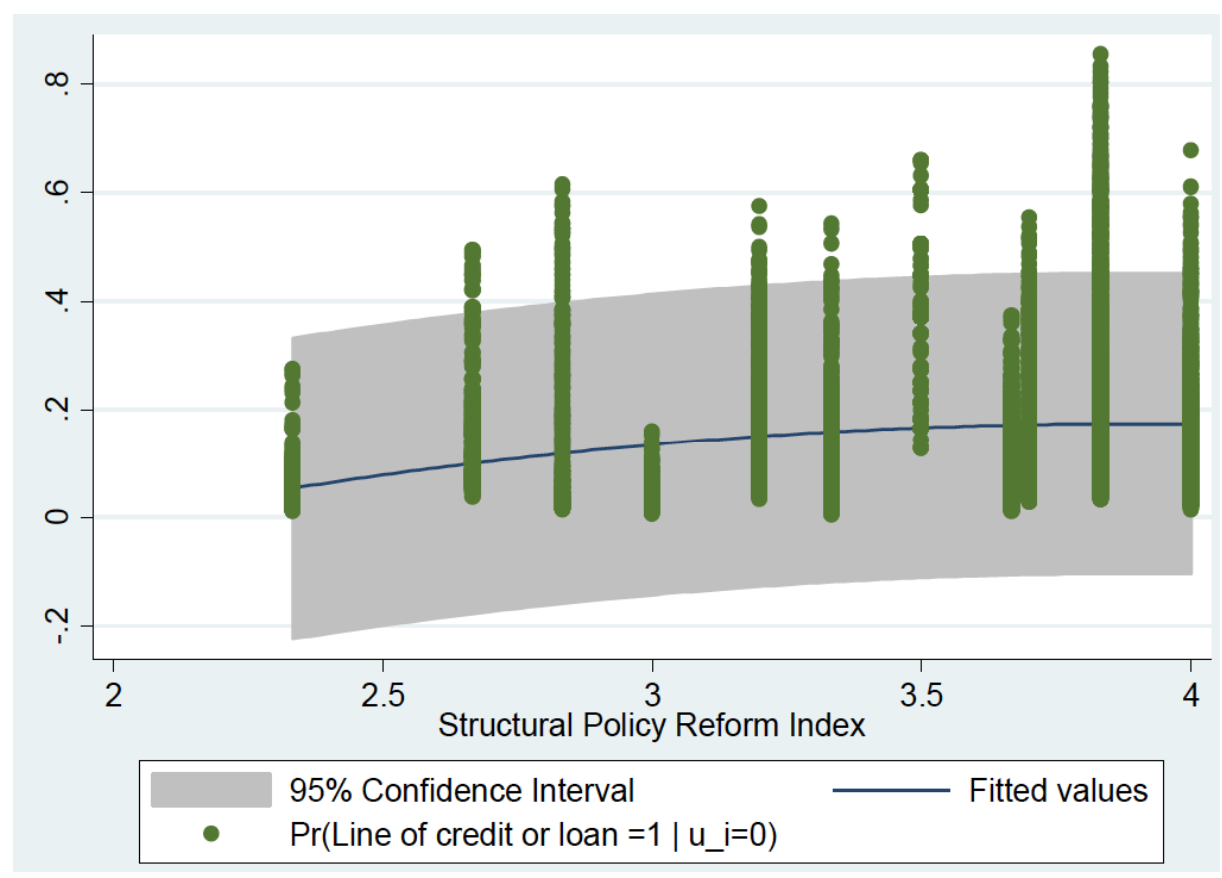

Figure 3: Structural Reforms and Debt Financing.

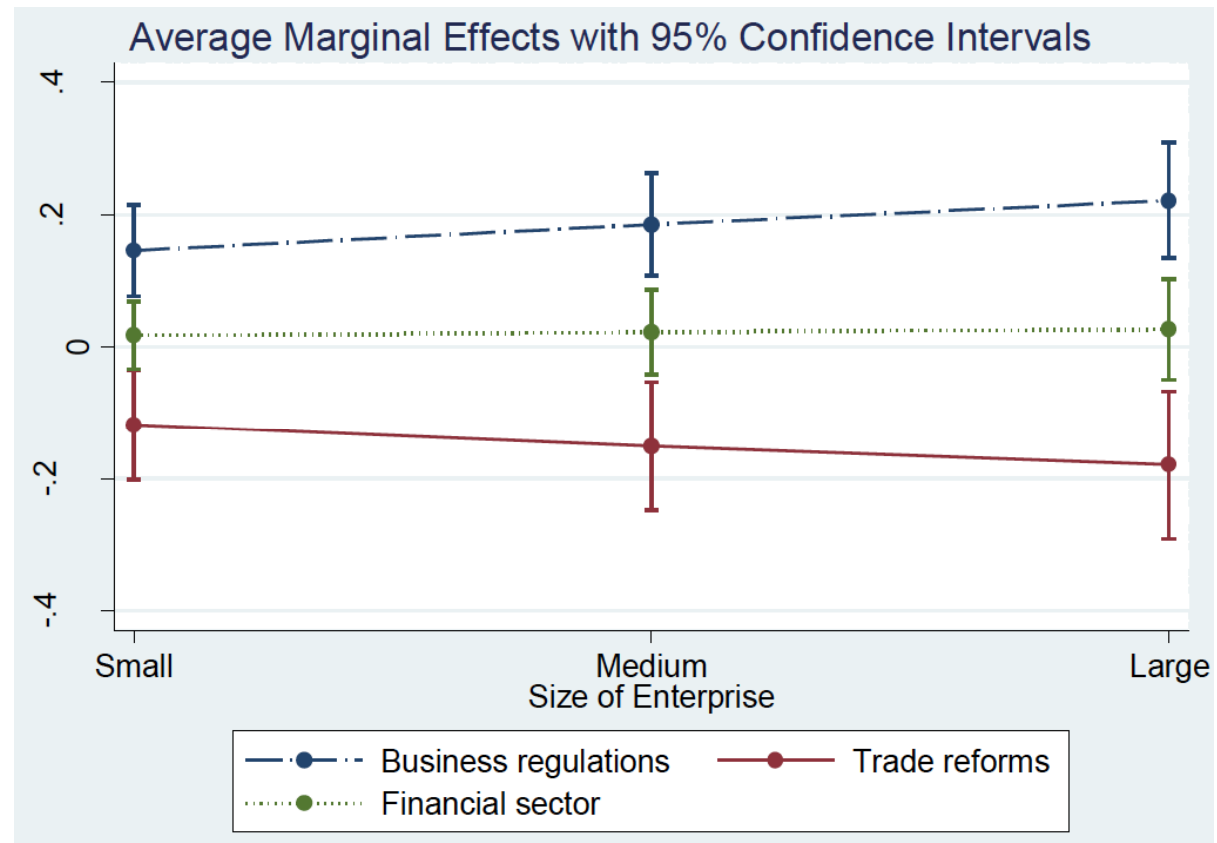

Figure 4: Business Environment Regulations, Trade, and Financial Sector Reforms-By Size.

10 percent increase in the index on the business regulatory environment, and financial sector reforms increases the probability of access to debt financing for working capital purposes by 0.26 and 0.05 . However, the effect on access to debt finance by increases in the index on trade sector reforms is negative. Specifically, a 10 percent increase in the index on trade sector reforms reduces the probability of access to debt finance by 0.33 .
There is heterogeneity in the results. Figure 4 illustrates the average marginal effects of all three policy variables by the size of the enterprises. From the figure, reforms in the business regulatory environment benefit large enterprises more than small ones. Financial sector reforms affect businesses of all sizes relatively equally. However, the adverse effects of trade sector reforms affect big business more than the small ones. These results hold for all countries in the sample. 
Table 5: Random Effects Estimates for Credit Model using CPIA-Full Model

\begin{tabular}{|c|c|c|c|}
\hline \multicolumn{4}{|c|}{ Dependent variable: credit } \\
\hline & (1) & $(2)$ & (3) \\
\hline \multirow[t]{2}{*}{ In(business regulations) } & $1.378^{* \star *}$ & $2.381^{* \star *}$ & $2.628^{* * * *}$ \\
\hline & $(0.175)$ & $(0.259)$ & $(0.264)$ \\
\hline \multirow[t]{2}{*}{ In(trade) } & $-3.393^{* \star *}$ & $-2.838^{* * *}$ & $-3.265^{* \star *}$ \\
\hline & $(0.327)$ & $(0.371)$ & $(0.393)$ \\
\hline \multirow[t]{2}{*}{ In(financial sector) } & $1.029^{* * *}$ & $0.549^{*}$ & 0.324 \\
\hline & $(0.171)$ & $(0.218)$ & $(0.224)$ \\
\hline \multirow[t]{2}{*}{ Private sector $\mathrm{Cr} / \mathrm{GDP}$} & & $0.822^{* *}$ & 0.538 \\
\hline & & $(0.303)$ & $(0.310)$ \\
\hline \multirow[t]{2}{*}{$\ln ($ size $)$} & & $0.526^{* * *}$ & $0.491^{* * *}$ \\
\hline & & $(0.0636)$ & $(0.0629)$ \\
\hline \multirow[t]{2}{*}{$\ln ($ age $)$} & & $0.109^{* * *}$ & $0.122^{* * *}$ \\
\hline & & $(0.0185)$ & $(0.0193)$ \\
\hline \multirow[t]{2}{*}{ Foreign-owned } & & $-0.158^{\star \star}$ & $-0.175^{* *}$ \\
\hline & & $(0.0606)$ & $(0.0612)$ \\
\hline \multirow[t]{2}{*}{ Trade credit } & & $0.512^{* * *}$ & $0.496^{* \star *}$ \\
\hline & & $(0.0545)$ & $(0.0540)$ \\
\hline \multirow[t]{2}{*}{ Share traded } & & 0.0725 & 0.178 \\
\hline & & $(0.0600)$ & $(0.0643)$ \\
\hline \multirow[t]{2}{*}{ Female Manager } & & 0.0921 & 0.0632 \\
\hline & & $(0.0649)$ & $(0.0650)$ \\
\hline \multirow[t]{2}{*}{ Retail } & & -0.148 & -0.172 \\
\hline & & $(0.149)$ & $(0.151)$ \\
\hline \multirow[t]{2}{*}{ Services } & & -0.0629 & -0.0818 \\
\hline & & $(0.146)$ & $(0.147)$ \\
\hline \multirow[t]{2}{*}{ Manufacturing } & & -0.0543 & -0.0718 \\
\hline & & $(0.143)$ & $(0.144)$ \\
\hline \multirow[t]{2}{*}{ Sole Proprietorship } & & $-0.180^{* * *}$ & $-0.174^{* *}$ \\
\hline & & $(0.0536)$ & $(0.0536)$ \\
\hline Country controls & & Yes & Yes \\
\hline Year controls & & No & Yes \\
\hline$A / C$ & 9739.1 & 6981.1 & 6957.4 \\
\hline$B I C$ & 9774.8 & 7099.4 & 7082.6 \\
\hline Observations & 9366 & 7754 & 7754 \\
\hline
\end{tabular}

Marginal effects; Standard errors in parentheses (d) for discrete change of dummy variable from 0 to $1 ;{ }^{*} p<0.05,{ }^{* *} p<0.01,{ }^{* * *} p<0.001$.

The impact of trade sector reforms is negative and provides a reason for policymakers to rethink some of the reforms. From Figure 5, trade sector reforms initially increase the likelihood of debt financing by 20 percent until a policy score of 3.5. Beyond a score of 3.5 , progressive reforms in the trade sector reduce the probability by as much as 13 percent below the initial rate, thereby negating the gains from the initial improvements. There is a repeat of the analysis for three countries in the sample to investigate potential heterogeneity in the results across countries. The countries include Rwanda, Angola, and the Congo Democratic Republic. Panels A, B, and C of Figure 6 shows the results. Again, there is heterogeneity in the 


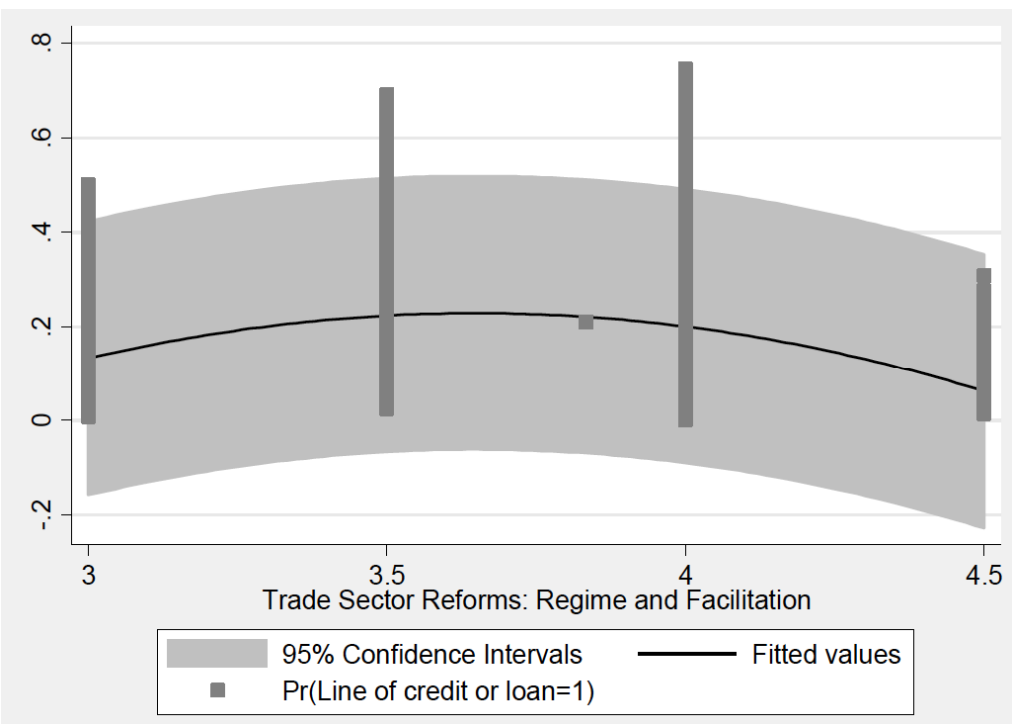

Figure 5: Trade Sector Reforms.

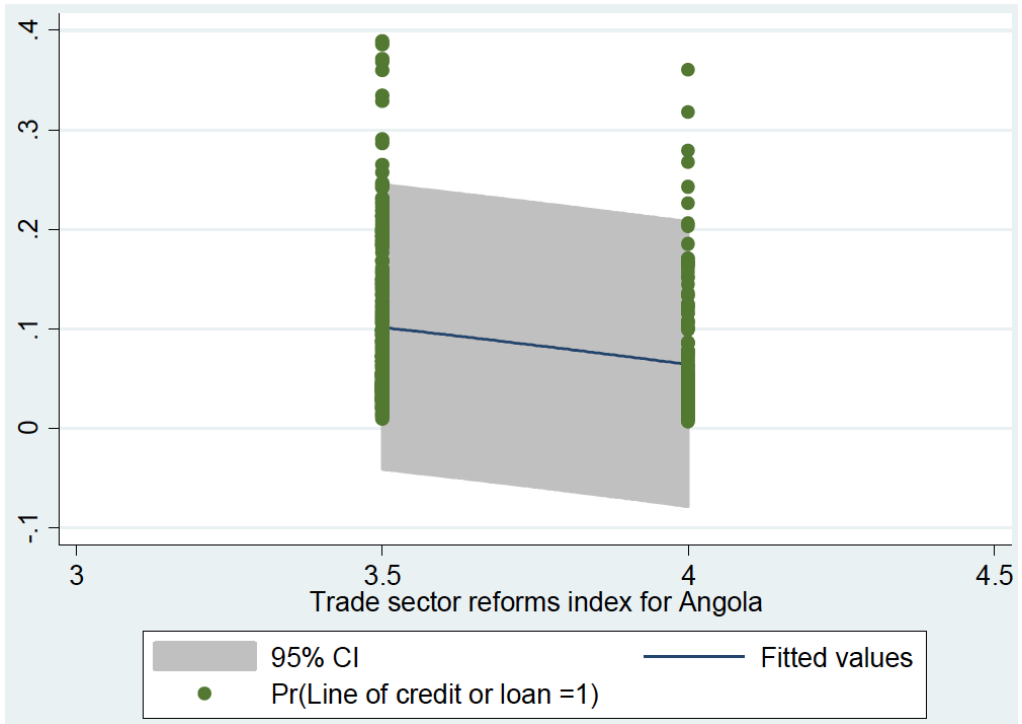

A

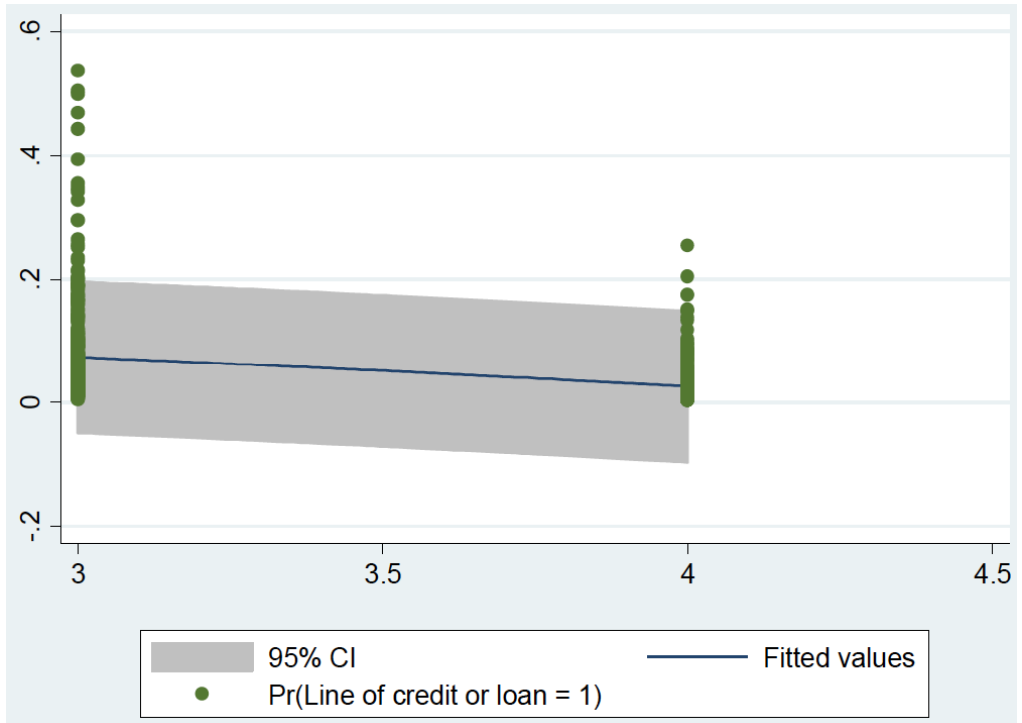

B 
(Figure 6). Continued.

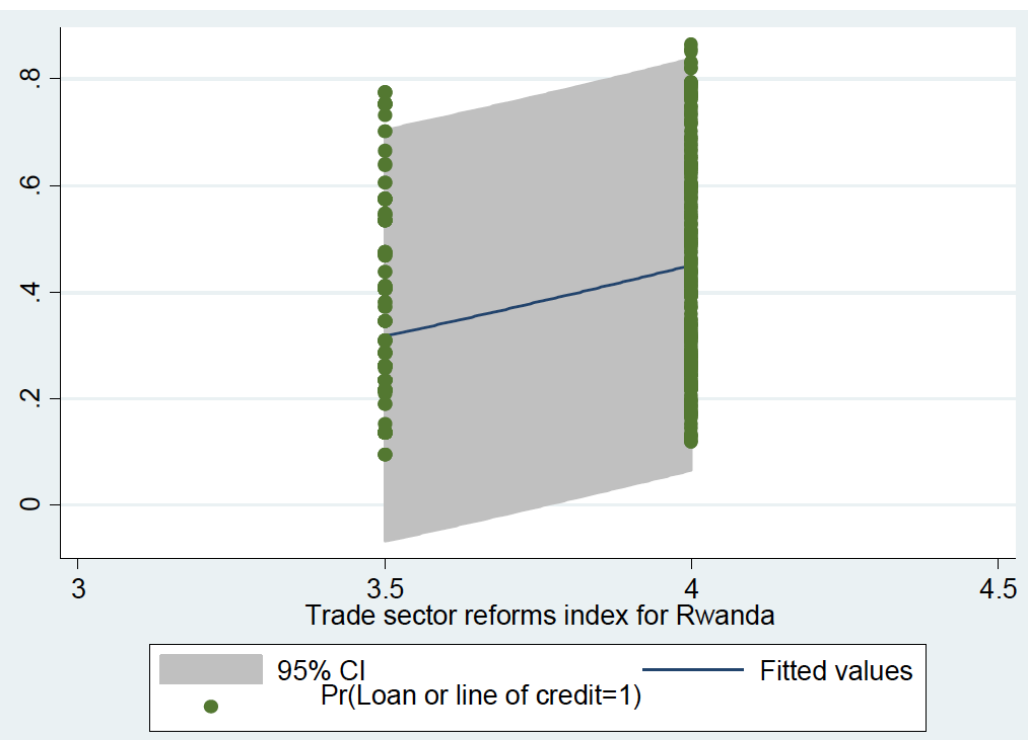

C

Figure 6: Panel A: Angola. Panel B: Democratic Republic of Congo. Panel C: Rwanda.

results. From $6 \mathrm{~A}$ and $6 \mathrm{~B}$ indicate that the marginal effects on access to debt financing for increases in the score in the trade sector are negative for Angola and Democratic Republic of Congo. However, as Figure 6C shows, the effect is positive for Rwanda.

Table 6 present the marginal effects of the threeway error component model for the derived ordered outcome variable, status. As reported, reform is statistically significant at 1 percent with a negative sign. The negative coefficient is indicative that progressive structural changes have the potential to ease debt financing constraints facing enterprises. Again, the control variables in the model do not have causal interpretations. Further, the qualitative inference from Table 6 is consistent with the results presented on the credit model.

\section{ROBUSTNESS CHECKS}

One threat to the internal validity of the econometric model is the problem of attrition-the nonresponsiveness of a unit in the next wave, in this case, an enterprise, after the first round of data collection. A non-response could be due to the operation shutting down, or a refusal by the business to participate in the survey. It is not possible to tell ahead of time the cause of the non-response. As Baltagi (2012) notes, attrition can potentially distort the random sampling design. If the non-response is not random, inference from the analysis of the population can potentially be misleading as the data may not be representative of the population.
Testing for attrition follows Verbeek \& Nijman (1992). The first step involves creating a dummy variable that takes a value of one if the enterprise is reinterviewed, and zero otherwise. This variable becomes an additional covariate. If the coefficient on the dummy variable has a $p$-value $\leq 0.05$, the conclusion is that there is attrition bias. In the credit model, the dummy variable on attrition has a coefficient of -0.01 , a standard error of 0.047 , and a p-value of 0.830 . In the Status model, the coefficient is 0.042 with a standard error of 0.026 , and a p-value of 0.112 . These results are indicative that there is not enough evidence to conclude that there is a problem of attrition in the model. Hence, inferences from the model are valid.

Cage (2013) has questioned the usefulness of the CPIA measures on policy performance. According to Cage, the CPIA policy variables positively correlate with output and are weak predictors of future economic growth. Consequently, to test the robustness of the results, there is a repeat of the analysis, using policy variables on Economic Freedom of the World Index (EFI) from the Fraser Institute, reported by Gwartney, Lawson, \& Hall (2013). The following discussion draws heavily from Gwartney, Lawson, \& Hall (2013). According to Gwartney, Lawson, \& Hall (2013), the building blocks of economic freedom include "personal choice, voluntary exchange, freedom to entering markets and compete, and security of the person and privately owned property." Again, according to Gwartney, Lawson, \& Hall (2013), the index depends 
Table 6: Random Effects Probit Estimates for the Baseline Status Model

\begin{tabular}{|c|c|c|c|c|c|}
\hline \multicolumn{6}{|c|}{ Dependent variable: Status } \\
\hline & (1) & (2) & (3) & (4) & (5) \\
\hline $\ln ($ reform $)$ & $\begin{array}{l}-0.646 \\
(0.103)\end{array}$ & $\begin{array}{l}-0.400^{*+2} \\
(0.108)\end{array}$ & $\begin{array}{c}-0.460^{\circ *} \\
(0.112)\end{array}$ & $\begin{array}{c}-0.755^{* 1 *} \\
(0.160)\end{array}$ & $\begin{array}{c}-0.728 \\
(0.160)\end{array}$ \\
\hline Private sector $\mathrm{Cr} / \mathrm{GDP}$ & & $\begin{array}{c}-1.171^{1 * *} \\
(0.166)\end{array}$ & $\begin{array}{c}-1.180^{\circ * *} \\
(0.177)\end{array}$ & $\begin{array}{l}-0.975^{* *} \\
(0.192)\end{array}$ & $\begin{array}{c}-0.813^{* *} \\
(0.197)\end{array}$ \\
\hline $\ln ($ size) & & & $\begin{array}{l}-0.390^{4 * *} \\
(0.0371)\end{array}$ & $\begin{array}{l}-0.384 \\
(0.0371)\end{array}$ & $\begin{array}{l}-0.374^{* * *} \\
(0.0372)\end{array}$ \\
\hline $\ln ($ age $)$ & & & $\begin{array}{l}-0.00856 \\
(0.0115)\end{array}$ & $\begin{array}{l}-0.0104 \\
(0.0116)\end{array}$ & $\begin{array}{l}-0.0106 \\
(0.0116)\end{array}$ \\
\hline Foreign-owned & & & $\begin{array}{l}-0.190^{* * * *} \\
(0.0396)\end{array}$ & $\begin{array}{l}-0.194^{* * *} \\
(0.0397)\end{array}$ & $\begin{array}{l}-0.189^{* * *} \\
(0.0397)\end{array}$ \\
\hline Trade credit & & & $\begin{array}{l}-0.279^{* \prime \prime} \\
(0.0283)\end{array}$ & $\begin{array}{l}-0.282 \\
(0.0283)\end{array}$ & $\begin{array}{l}-0.282 \\
(0.0284)\end{array}$ \\
\hline Share traded & & & $\begin{array}{l}-0.182^{* * *} \\
(0.0373)\end{array}$ & $\begin{array}{l}-0.198 \\
(0.0378)\end{array}$ & $\begin{array}{l}-0.233^{* * *} \\
(0.0395)\end{array}$ \\
\hline Female Manager & & & $\begin{array}{c}0.0232 \\
(0.0402)\end{array}$ & $\begin{array}{c}0.0157 \\
(0.0404)\end{array}$ & $\begin{array}{c}0.0234 \\
(0.0405)\end{array}$ \\
\hline Retail & & & $\begin{array}{c}-0.0627 \\
(0.0763)\end{array}$ & $\begin{array}{l}-0.0880 \\
(0.0771)\end{array}$ & $\begin{array}{l}-0.0753 \\
(0.0773)\end{array}$ \\
\hline Services & & & $\begin{array}{c}0.0510 \\
(0.0746)\end{array}$ & $\begin{array}{c}0.0181 \\
(0.0759)\end{array}$ & $\begin{array}{c}0.0300 \\
(0.0761)\end{array}$ \\
\hline Manufacturing & & & $\begin{array}{c}0.0940 \\
(0.0716)\end{array}$ & $\begin{array}{c}0.0577 \\
(0.0731)\end{array}$ & $\begin{array}{c}0.0666 \\
(0.0732)\end{array}$ \\
\hline Sole Proprietorship & & & $\begin{array}{c}0.0257 \\
(0.0338)\end{array}$ & $\begin{array}{c}0.0181 \\
(0.0340)\end{array}$ & $\begin{array}{c}0.0159 \\
(0.0340)\end{array}$ \\
\hline Country controls & & & No & Yes & Yes \\
\hline Year controls & & & No & No & Yes \\
\hline$A / C$ & 21069.1 & 21008.7 & 18427.3 & 18421.9 & 18416.3 \\
\hline$B I C$ & 21103.9 & 21050.4 & 18537.0 & 18538.5 & 18539.7 \\
\hline Observations & 7756 & 7756 & 7010 & 7010 & 7010 \\
\hline
\end{tabular}

Marginal effects; Standard errors in parentheses (d) for discrete change of dummy variable from 0 to $1 ;{ }^{*} p<0.05,{ }^{* *} p<0.01,{ }^{* * *} p<0.001$.

on 42 subcomponents grouped into five main areas. The five areas include "the size of government including expenditures, taxes, and enterprises; security of property rights; access to sound money; freedom to trade internationally; and regulation of credit, labor, and business." For this study, the last two constitute the relevant primary variables as they correlate with the policy variables from the CPIA reported earlier. The index involves data from the International Monetary Fund, World Bank, and the World Economic Forum. Each component and sub-component are rated on a scale of zero to 10 , with ten corresponding to higher freedom.
Concerning freedom to trade internationally, the object is to measure the extent to which goods and services and financial assets can move across borders without impediments. The barriers take the form of tariffs, quotas, and capital controls. A country with low import tariffs and fewer capital controls gets a high rating. Within the sub-component on import tariffs, countries with no import taxes get a score of ten. However, countries with import taxes greater than 15 percent get a zero rating. The credit market and business regulations component focus on the extent to which the regulatory environment constraints freedom of exchange in the credit, labor and goods markets. 
Table 7: Random Effects Estimates for Credit Model using EFW

\begin{tabular}{|c|c|c|c|}
\hline \multicolumn{4}{|c|}{ Dependent variable: credit } \\
\hline \multirow[t]{2}{*}{ In(Freedom to trade) } & $-0.677^{* * *}$ & $-0.959^{* * * *}$ & $-1.088^{* * *}$ \\
\hline & $(0.117)$ & $(0.147)$ & $(0.151)$ \\
\hline \multirow[t]{2}{*}{ In(Business environment) } & $1.622^{* * *}$ & $0.880^{* * *}$ & $0.787^{*+*}$ \\
\hline & $(0.152)$ & $(0.190)$ & $(0.191)$ \\
\hline Private sector $\mathrm{Cr} / \mathrm{GDP}$ & & $(0.290)$ & $(0.293)$ \\
\hline \multirow[t]{2}{*}{$\ln ($ size $)$} & & $0.518^{* * *}$ & $0.493^{* * *}$ \\
\hline & & $(0.0636)$ & $(0.0631)$ \\
\hline $\ln ($ age $)$ & & $0.110^{* * *}$ & $0.117^{\star \star *}$ \\
\hline \multirow[t]{2}{*}{ Trade credit } & & $0.606^{* * *}$ & $0.612^{* * *}$ \\
\hline & & $(0.0581)$ & $(0.0585)$ \\
\hline \multirow[t]{2}{*}{ Share traded } & & 0.0456 & 0.128 \\
\hline & & $(0.0609)$ & $(0.0655)$ \\
\hline \multirow[t]{2}{*}{ Female Manager } & & 0.126 & 0.114 \\
\hline & & $(0.0655)$ & $(0.0653)$ \\
\hline \multirow[t]{2}{*}{ Retail } & & $-0.311^{*}$ & $-0.357^{*}$ \\
\hline & & $(0.156)$ & $(0.159)$ \\
\hline Sole Proprietorship & & $(0.0549)$ & $(0.0549)$ \\
\hline Country controls & & $-0.124^{* *}$ & $-0.139^{* *}$ \\
\hline Year controls & & $(0.0430)$ & $(0.0436)$ \\
\hline$A I C$ & 9802.4 & 7083.7 & 7072.2 \\
\hline$B I C$ & 9831.0 & 7195.0 & 7190.4 \\
\hline Observations & 9366 & 7754 & 7754 \\
\hline
\end{tabular}

Marginal effects; Standard errors in parentheses (d) for discrete change of dummy variable from 0 to $1 ;{ }^{*} p<0.05,{ }^{* \prime \prime} p<0.01,{ }^{\prime \prime \prime} p<0.001$.

According to Gwartney, Lawson, \& Hall (2013), countries with privately held deposits greater than 95 percent receive a score of ten. Countries with private deposits of between 75 percent and 95 percent get a rating of 8 ; between 40 percent and 75 percent get a score of 5; those between 10 percent and 40 percent, get a score of 2 ; those with private deposits of less than 10 percent get a score of zero. Also, concerning the labor market, countries that permit the forces of demand and supply in the labour market to determine wages receive higher rating than those that do not. The subcomponent on the goods market is concerned with the ease or otherwise of entry and exit into an industry. Countries with regulations that facilitate entry and exit into an industry receive a high rating.

Table 7 presents the results for the credit model. The coefficient on the variable freedom to trade internationally, which is comparable to trade sector reforms in the CPIA is statistically significant at 1 


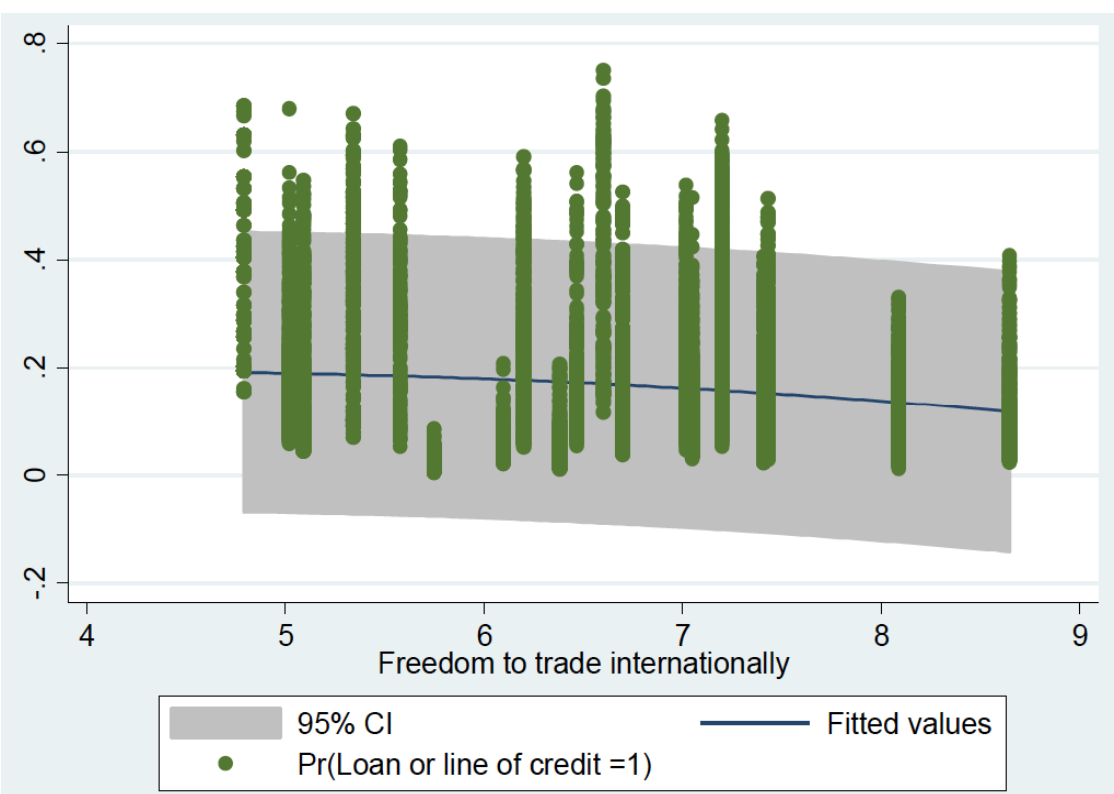

Figure 7: Freedom to Trade Internationally.

percent and with a negative sign, as expected. A 10 percent increase in the index on freedom to trade internationally reduces the probability of access to a line of credit or loan by 0.11 . Numerically, the decrease of 0.11 from this result is different from the 0.33 reduction obtained from the policy variables from the CPIA, but the conclusion is the same: Reforms in the trade sector do not necessarily make it easier for enterprises to access debt finance. Figure 7 illustrates the results. Also, the coefficient on the variable credit market and business regulations is statistically significant at 1 percent with a positive sign. Again, qualitatively, this result is consistent with the results from the main model. A 10 percent increase in the variable credit market and business regulations increases the probability of access to debt finance by 0.08 . The previous result using the policy variable from the CPIA is 0.05 .

\section{DISCUSSION AND CONCLUSIONS}

The study examines the question: Are the structural policy reforms, supported by the World Bank effective in reducing debt financing constraints facing formal sector enterprises? Structural policy index (reform), as defined by the World Bank, constitute the primary explanatory variable. It is an index consisting of the trade sector, financial sector, and reforms in the business regulatory environment. The results are indicative that taken together; structural policy reforms reduce debt financing constraints facing enterprises, at least, as it pertains to their working capital needs. There is heterogeneity in the results. Changes in the business regulatory environment benefit large firms more than small ones. Financial sector reforms affect enterprises of all sizes relatively equally. There is additional heterogeneity in the consequences of trade sector reforms. For all the twelve countries, together, trade sector reforms initially increase the likelihood of debt financing by 20 percent until a policy score of 3.5. Beyond a score of 3.5 , progressive reforms in the trade sector reduce the probability by as much as 13 percent, thereby negating the gains from the initial improvements. Also, not all countries experience the same effects from trade sector reforms. Improvements in the score on trade sector reforms have adverse effects on the probability of access to debt finance by enterprises in Angola and Democratic Republic of Congo, for instance. However, the effect is positive for Rwanda.

The problem is, the reforms prescribed by the World Bank in most of the countries in sub-Saharan Africa are uniform. As demonstrated, the reforms supported by the World Bank are not making the anticipated impact, at least in the credit market and the effects are not uniform across countries. The results on the impact of trade sector reforms provide an opportunity to rethink some of the policies promoted in developing countries. For instance, according to the guidelines for the CPIA rating on trade sector reforms, a country gets a score of one if the average most favored nation (MFN) tariff in addition to all other import taxes is above 20 percent, and with peaks above 50 percent. A country gets a score of three out of six if the average MFN in addition to all other import taxes is between $15-20$ percent, and 
receives a rating of four out of six if the import tax is between 10 and 15 percent. A country gets a score of six if the average MFN tariff in addition to import taxes is 5 percent. The results of the study are indicative that, reducing the average most favored nation tariff in addition to all other import taxes below 15 percent could negatively affect local enterprises due to the potential competition from imports. The competition makes the balance sheets of the local businesses worse, thereby making it harder to attract debt financing.

On the other hand, there is empirical support for continuous reforms in the business regulatory environment and the financial sector. Reforms in the financial sector could involve expansion of credit to the private sector, encouraging the expansion of branch networks of financial institutions. The changes could also mean opening up of capital markets for international investment, and enacting laws that promote diversification of financial markets. Reforms could also include improvements in records on information about credit history and property registration. Further changes could mean promoting competition in the banking sector to avoid bank concentration, and discouraging the tendency of commercial banks to hold government debt instead of lending to private enterprises. Potential reforms could involve promoting competition in the industry, and changes that cut the cost and time of doing business, which also includes the cost of starting one. These changes are essential to reducing poverty and promoting economic growth in developing countries.

As a result of the identification strategy adopted, the study had some limitations. The analyses involve panel data models. However, there were only two data points $(T=2)$ for each enterprise in the sample. For instance, for enterprises in Tanzania, the first data collection occurred in 2006, while the second took place in 2013. The study could have benefited a lot from more data points. However, notwithstanding this limitation on the data, the results are empirically robust.

\section{REFERENCES}

Abor, J., \& Quartey, P. 2010. "Issues in SME Development in Ghana and South Africa." International Research Journal of Finance and Economics, 39(39), 218-228.

Ayyagari, M., Demirguc-Kunt, A., \& Maksimovic, V. 2011. "Small vs. young firms across the world: contribution to employment, job creation, and growth." World Bank Policy Research Working Paper Series, (April), 1-57.

Ayyagari, M., Demirgüç-Kunt, A., \& Maksimovic, V. 2008. "How important are financing constraints? The role of finance in the business environment." World Bank Economic Review, 22(3), 483-516.

http://dx.doi.org/10.1093/wber//hn018

Baltagi, B. H. 2008. Econometric analysis of panel data. Chichester, UK: John Wiley \& Sons.

Beck, T., \& Demirguc-Kunt, A. 2006. "Small and medium-size enterprises: Access to finance as a growth constraint." Journal of Banking and Finance, 30(11), 2931-2943. http://dx.doi.org/10.1016/j.jbankfin.2006.05.009

Beck, T., Demirgüç-kunt, A., Honohan, P., Beck, T., Demirgüc-kunt, A., \& Honohan, P. 2009. "Access to Financial Services: Measurement Impact and Policies." World Bank Research Observer, 24(1), 119-145. http://dx.doi.org/10.1093/wbro/lkn008

Bigsten, A., Collier, P., \& Dercon, S. 2003. "Credit Constraints in Manufacturing Enterprises in Africa."Journal of African Economics, 12(1), 104-125. http://dx.doi.org/10.1093/jae/12.1.104

Burkart, M., \& Ellingsen, T. 2004. "In-kind finance: A theory of trade credit." American Economic Review, 94(3), 569-590. http://dx.doi.org/10.1257/0002828041464579

Cassar, G. 2004. "The financing of business start-ups." Journal of Business Venturing, 19(2), 261-283. http://dx.doi.org/10.1016/S0883-9026(03)00029-6

Du, J., \& Girma, S. 2012. "Firm Size, Source of Finance, and Growth - Evidence from China." International Journal of the Economics of Business, 19(3), 397-419. http://dx.doi.org/10.1080/13571516.2012.715272

Fazzari, S. M., Hubbard, R. G., \& Petersen, B. C. 2000. "Investmentcash flow sensitivities are useful: A comment on Kaplan and Zingales." Quarterly Journal of Economics, 115(2), 695-705. http://dx.doi.org/10.1162/003355300554773

Fazzari, S. M., Hubbard, R. G., Petersen, B. C., Blinder, A. S., \& James, M. 1988. "Financing Corporate Constraints Investment." Brookings Papers on Economic Activity, 1(1) 141-206. http://dx.doi.org/10.2307/2534426

Greene, W. H. 2012. Econometric Analysis. Prentice Hall (Vol. 97).

Gurley, J. G., \& Shaw, E. S. 1955. "Financial Aspects of Economic Development." The American Economic Review, 45(4), 515538.

Gwartney, J., Lawson, R., \& Hall, J. 2013. Economic Freedom Dataset published in Economic Freedom of the World. Fraser Institute

Julia Cage, 2015. "Measuring Policy Performance: Can We Do Better than the World Bank?," Sciences Po publications

Kaplan, Steven and Luigi Zingales. 1997. "Do Financing Constraints Explain Why Investment is Correlated with Cash Flow?" Quarterly Journal of Economics, CXII, 169-215. http://dx.doi.org/10.1162/003355397555163

Kaplan, S. N., \& Zingales, L. 2000. "Investment-Cash Flow Sensitivities Are Not Valid Measures of Financing Constraints." The Quarterly Journal of Economics, 115(2), 707-712. http://dx.doi.org/10.1162/003355300554782

Kuntchev, V., 2014. What have we learned from the Enterprise Surveys regarding access to finance by SMEs? Enterprise Analysis Unit, (May), pp. 1-35.

Schumpeter, J. A. 1934. The Theory of Economic Development. Harvard University Press.

Smith, J. K. 1987. "Trade Credit and Informational Asymmetry." The Journal of Finance, 42(4), 863-872. http://dx.doi.org/10.1111/j.1540-6261.1987.tb03916.x

Petersen, M. a., \& Rajan, R. G. 1997. "Trade Credit: Theories and Evidence." Review of Financial Studies, 10(3), 661-691. http://dx.doi.org/10.1093/rfs/10.3.661 
Pfarr, C. 2011. "Estimating Ordered Categorical Variables Using Panel Data: A Generalised Ordered Probit Model with an Autofit Procedure," Stata Journal 54(1), 7-23.

The World Bank. 2013. Doing Business 2013.

The World Bank. 2013. Country Policy And Institutional Assessment Reports (Includes Djibouti and Yemen) 98118.
Tirole, J. 2006. The theory of corporate finance. Princeton, N.J: Princeton University Press.

Verbeek, M., \& Nijman, T. 1992. "Can cohort data be treated as genuine panel data?" Empirical Economics, 17(1), 9-23. http://dx.doi.org/10.1007/BF01192471

DOI: http://dx.doi.org/10.6000/1929-7092.2016.05.28

(C) 2016 Prosper Senyo Koto; Licensee Lifescience Global.

This is an open access article licensed under the terms of the Creative Commons Attribution Non-Commercial License (http://creativecommons.org/licenses/by-nc/3.0/) which permits unrestricted, non-commercial use, distribution and reproduction in any medium, provided the work is properly cited. 